\title{
PROFIL PILIHAN KARIR SISWA SETELAH LULUS SMA BERDASARKAN SUKU (TIONGHOA, DAYAK, MELAYU DAN MADURA) DI KOTA SINGKAWANG
}

\author{
Dewi Mariana ${ }^{1}$, Slamat Fitriyadi ${ }^{2}$, Restu Aji Utomo ${ }^{3}$ \\ STKIP Singkawang, , STKIP Singkawang ${ }^{2}$, STKIP Singkawang 3 \\ anieng_dewi@yahoo.co.id ${ }^{1}$, ahmadfitriyadi521@gmail.com ${ }^{2}$, restuaji962@gmail.com ${ }^{3}$
}

\begin{tabular}{ll}
\hline \hline Kata Kunci: & ABSTRAK \\
Pilihan Karir, Suku & Penelitian ini bertujuan untuk mengetahui arah karir \\
& minat siswa berdasarkan suku (tionghoa, dayak, melayu \\
& dan madura); Penelitian yang digunakan adalah \\
penelitian kualitatif. Dalam penelitian ini subjek yang \\
digunakan sebanyak empat puluh subjek yang dianggap \\
mampu memberikan data yang peneliti inginkan. Objek \\
pada penelitian ini ditentukan berdasarkan situasi sosial. \\
Pada situasi sosial atau objek penelitian ini peneliti dapat \\
mengamati secara mendalam aktivitas (activity) orang- \\
orang (actors) yang ada pada tempat (place) tertentu. \\
Hasil penelitian ini menunjukan bahwa arah karir siswa \\
berdasarkan suku: a. Etnis tioghoa melanjutkan ke \\
Perguruan Tinggi. b. Suku dayak melanjutkan ke \\
Perguruan Tinggi. c. Suku melayu melanjutkan ke dunia \\
kerja. d. Suku madura melanjutkan ke Perguruan Tinggi. \\
\hline
\end{tabular}

\section{PENDAHULUAN}

Pendidikan dapat dikatakan berhasil jika seseorang dapat merealisasikan cita-citanya. Cita-cita merupakan harapan yang dimiliki oleh setiap manusia. Salah satu faktor yang dapat menimbulkan citacita ialah minat yang dimiliki seseorang. Minat adalah sesuatu yang pribadi dan berhubungan dengan sikap, individu yang berminat terhadap suatu obyek akan mempunyai kekuatan atau dorongan untuk melakukan serangkaian tingkah laku untuk mendekati atau mendapatkan objek tersebut.

Karir diartikan sebagai rentangan peran kehidupan individu yang berjalan sepanjang hayat, baik ketika masa belajar, masa bekerja, ataupun masa pensiun. Pada setiap rentang kehidupan terdapat tugas dan harapan karir, termasuk didalamnya tugas dan harapan karir siswa SMA. Suatu pekerjaan bagi siswa SMA merupakan sesuatu yang secara sosial diakui sebagai cara untuk memenuhi kepuasan berbagai kebutuhan, mengembangkan perasaan eksis dalam masyarakat, dan memperoleh sesuatu yang diinginkan untuk mencapai tujuan hidup. Untuk mencapai tujuan hidup tersebut individu memerlukan gambaran atau profil karir. Profil merupakan pandangan sisi, garis besar, atau biografi dari diri seseorang atau kelompok yang memiliki usia yang sama.

Menurut Super pada kenyataan yang ada, masih sering dijumpai permasalahan karir baik dari internal maupun eksternal diri siswa. Permasalahan karir tersebut dapat dihindari dengan memiliki pemahaman akan orientasi karir. Orientasi karir merupakan sikap individu terhadap pilihan karir, baik itu pilihan 
studi lanjut ataupun pilihan pekerjaan yang ditunjukkan dengan adanya pengetahuan diri, pemahaman diri, kemampuan diri, dan perencanaan masa depan. Orientasi karir seseorang dipengaruhi beberapa faktor antara lain adalah pengaruh lingkungan keluarga dan stimulus budaya keluarga.

Budaya keluarga sebagai mekanisme kontrol pola pikir dan keterkaitannya dengan orientasi karir dapat dilihat dari keberagaman etnis. Etnis merupakan suatu kosep yang menggambarkan sekelompok manusia yang mempunyai ikatan kebudayaan dan kesamaan identitas yang berasal dari persamaan kebangsaan, suku, ras, maupun agama. Seseorang yang berasal dari keturunan keluarga etnis tertentu akan mempunyai suatu identitas yang mejadikan dirinya merasa memiliki dan menjadi bagian dari kelompok suatu etnis. Perbedaan kebudayaan antar etnis akan melahirkan sebuah kepribadian yang akan menentukan sikap, perilaku, nilai dan orientasi hidup, termasuk didlamnya akan menghasilkan perbedaan orientasi pada karir individu.

Pemilihan karir yang baik pada jenjang sekolah menengah atas merupakan langkah awal untuk menghasilkan angkatan.Perbedaan yang terjadi pada arah karir siwa berdasarkan etnis yang kita ketahui seperti etnis tionghoa yang kebanyakan memilih untuk melanjutkan kedunia kerja dibanding melanjutkan ke perguruan tinggi, jika melanjutkan ke perguruan tinggi etnis tionghoa lebih cenderung mengambil bidang ekonomi, sedangkan pada suku dayak kebanyakan memilih untuk ikut orang tua mengurus perkebunan yang dimiliki oleh orang tua jika melanjutkan ke perguruan tinggi mereka lebih memilih bidang teknik, pada suku melayu kebanyakan dari mereka melanjutkan ke perguruan tinggi dan mengambil berbagai bidang seperti keguruan dan kesehatan, tidak banyak dari mereka yang lebih memilih untuk mengikuti teman dalam memilih perguruan tinggi, lalu pada suku madura kebanyakan dari mereka lebih memilih untuk melanjutkan kedunia kerja seperti menjadi tenaga kerja indonesia diluar negeri.

Kemampuan dalam merencanakan karir perlu dimiliki setiap individu termasuk siswa di sekolah. Perencanaan karir yang dimiliki oleh siswa berguna untuk pemilihan jenis studi lanjut dan pemilihan rencana pekerjaan. Salah satunya pada siswa tingkat menengah atas. Siswa SMA tentunya sudah memiliki pemikiran kemana arah tujuan kedepannya jika telah berada di tingkat akhir atau kelas XI. Siswa di tiap sekolah tentunya memiliki latar belakang suku atau etnis yang berbeda-beda, diantaranya Tionghoa, dayak, melayu dan madura.

Dari keberagaman etnis di Kota Singkawang, pada Sekolah Menengah Atas (SMA) akan terdapat siswa yang termasuk dalam etnis tersebut. Dari keberagaman inilah dapat menjadikan perbedaan dalam hal pemilihan karir pada siswa SMA. Berdasarkan latar belakang yang telah diuraikan, peneliti akan meneliti pilihan karir minat siswa berdasarkan suku atau etnis.

\section{METODE}

Jenis penelitian ini adalah penelitian kualitatif. Lokasi penelitian dilaksanakan pada SMAN 7 Singkawang Timur, SMAN 6 Singkawag Utara, SMAN 3 Singkawang Tengah dan SMA St. Ignasius Singkawang Barat. Pada penelitian ini teknik pengambilan sampel menggunakan teknik purposive sampling. Dalam penelitian ini subjek yang digunakan sebanyak empat puluh subjek yang dianggap mampu memberikan data yang peneliti inginkan. Peneliti memberikan kriteria terhadap subjek penelitian yang berguna sebagai patokan subjek yang dianggap tepat dan dapat memberi data yang peneliti butuhkan. Objek penelitian ini adalah profil karir siswa setelah SMA. Teknik pengumpulan data yang digunakan yaitu wawancara dan dokumentasi.

Adapun langkah-langkah yang dilakukan dalam penelitian ini, yaitu peneliti melakukan pengamatan terkait keberagaman etnis dan suku di Kota Singkawang. Peneliti menentukan objek ang diteliti yaitu profil karir siswa setelah SMA. Untuk dapat memperoleh data mengenai gambaran arah karir siswa berdasarkan masing-masing suku dan etnis, maka peneliti melakukan wawancara dan dokumentasi untuk memperkuat keakuratan data. Sebelum melakukan wawancara, peneliti mempersiapkan 
pedoman wawancara. Setelah membuat pedoman, peneliti melakukan wawancara kepada masingmasing siswa berdasarkan etnis dan suku yang berbeda. Setelah data hasil wawancara terkumpul, dilakukan analisis data yaitu mereduksi data, display data, pengambilan keputusan dan verifikasi untuk memperoleh hasil arah minat karir siswa setelah lulus SMA.

\section{HASIL DAN PEMBAHASAN}

\section{SMAN 7 Singkawang Timur}

Siswa di SMAN 7 Singkawang memiliki latar belakang suku dan etnis yang berbeda, yaitu dayak, melayu dan jawa. Namun hampir $\pm 80 \%$ atau sekitar 366 mayoritas siswa disekolah tersebut berlatar belakang suku dayak. Sejalan dengan penelitian yang dilakukan, maka peneliti mengambil sasaran subjek yang berlatar belakang suku Dayak. Data yang diperoleh yaitu mayoritas siswa berlatar belakang suku dayak, akan memperkuat penelitian dalam mengetahui arah minat karir siswa setelah lulus SMA. Untuk memperoleh data informasi arah karir siswa, peneliti melakukan wawancara dengan 10 siswa yang berlatar belakang suku dayak. Wawancara yang dilakukan merupakan wawancara semiterstrukur. Point pertanyaan yang diajukan kepada responden atau siswa yaitu pertanyaan yang terkit dengan arah minat karir siswa setelah lulus SMA. Berdasarkan hasil wawancara yang telah dilakukan, sembilan dari sepuluh siswa memilih untuk melanjutkan ke Perguruan Tinggi dan satu orang memilih untuk melanjutkan kedunia kerja. Subjek menjelaskan bahwa akan melanjutkan ke perguruan tinggi setelah lulus SMA namun masih memiliki keterbatasan informasi mengenai Perguruan Tinggi yang akan dituju.

Suku dayak terkenal dengan berbagai macam kesenian tradisional yang telah menjadi warisan bagi keturuunannya, kesenian merupakan hal yang tak dapat dipisahkan dari suku dayak. Salah satu contoh kesenian yang ada adalah tarian yang bertemakan perang. Pada saat melaksanakan wawancara siswa memiliki jawaban yang beragam tentang pilihan karir yang berhubungan dengan melanjutkan ke Perguruan Tinggi tetapi dari jawaban yang beragam tersebut siswa tetap memiliki keinginan untuk melanjutkan di bidang kesenian dan berharap agar mereka kelak bisa melestarikan dan menjadikan kebudayaan mereka tidak dimakan zaman, berikut hasil wawancara yang dilakukan di SMAN 7 Singkawang.

Hasil wawancara diperoleh bahwa arah karir minat siswa berlatar belakang suku dayak setelah lulus SMA adalah melanjutkan ke Perguruan Tinggi. Faktor yang melatarbelakangi pilihan siswa untuk melanjutkan ke Perguruan Tinggi adalah keinginan untuk melestarikan kebudayaan serta mengembangkan bakat yang dimiliki dengan cara memilih Perguruan Tinggi dalam bidang seni dan budaya, hasil yang diperoleh dilapangan ternyata berbeda dengan praduga peneliti yang telah dijabarakan sebelumnya. Hal tersebut terjadi karena adanya keinginan yang dimiliki oleh siswa untuk melestarikan seni dan budaya agar tidak termakan oleh zaman.

2. SMAN 6 Singkawang Utara

Rata-rata siswa yang berada di SMAN 6 Singkawang memiliki latar belakang suku dan etnis yang berbeda yaitu batak, melayu, madura dan lain sebagainya. Namun $\pm 96 \%$ atau sekitar 273 mayoritas siswa disekolah tersebut berlatar belakanng suku melayu. Suku Melayu menjadi sasaran subjek penelitian untuk mengetahui arah minat karir siswa setelah lulus SMA. Untuk memperoleh jawaban tersebut, peneliti melakukan wawancara dengan 10 siswa yang berlatar belakang suku melayu. Pertanyaan yang diajukan terkait arah karir yang diminati siswa setelah lulus SMA. Berdasarkan hasil wawancara yang telah dilakukan, delapan dari sepuluh siswa memilih untuk bekerja dan dua orang siswa memilih untuk melanjutkan ke Perguruan Tinggi. Subjek menjelaskan bahwa akan melanjutkan kedunia kerja dikarenakan letak geografis antara rumah dan tempat kerja dekat dan untuk meringankan beban orang tua, memenuhi kebutuhan pribadi subjek. 
Hasil dari penelitian yang dilakukan dengan cara mewawancarai subjek yang berlatar belakng suku melayu menyatakan bahwa terdapat sebuah persepsi yang menganggap bahwa melanjutkan pendidikan setelah SMA bukanlah keputusan yang berpengaruh terhadap masa depan mereka. Kebanyakan dari mereka lebih memilih untuk bekerja diluar negeri dan lebih tertarik untuk membuka usaha dikarenakan dapat memberikan lapangan pekerjaan kepada orang banyak dan meningkatnya kebutuhan dan kurangnya penghasilan yang dialami oleh keluarga. Persepsi tersebut menjadi alasan yang kuat bagi mereka untuk tidak melanjutkan ke Perguruan Tinggi. Sedikit dari mereka yang memilih untuk melanjutkan ke Perguruan Tinggi sambil bekerja. Hal tersebut bertolak belakang dengan praduga peneliti yang telah dijelaskan sebelumnya yang menyatakan bahwa kebanyak dari suku melayu memilih untuk melanjutkan ke Perguruan Tinggi dikarenakan mengikuti teman teman yang berada dilingkungan sekitarnya.

\section{SMAN 3 Singkawang Tengah}

Rata-rata siswa memiliki latar belakang suku dan etnis yang berbeda-beda, namun $10 \%$ atau 51 siswa dari jumlah keseluruhan siswa berlatar belakang suku madura. Suku madura menjadi sasaran subjek yang diteliti peneliti untuk mengetahui arah minat karir siswa setelah lulus SMA. Peneliti melakukan wawancara dengan 10 siswa yang memiliki latar belakang suku madura. Terdapat beberapa pertanyaan yang diajukan peneliti kepada responden atau siswa terkait arah minat karir setelah SMA. Berdasarkan hasil wawancara yang dilakukan, delapan dari sepuluh siswa memilih untuk melanjutkan ke Perguruan Tinggi dan dua orang siswa memilih untuk bekerja. Subjek menjelaskan bahwa akan melanjutkan ke Perguruan Tinggi dikarenakan telah memiliki biaya untuk melanjutkan ke Perguruan Tinggi, dan telah didukung oleh orang tua.

Suku madura merupakan suku yang bukan berasal dari pulau kalimantan dan bisa dikatakan sebagai suku pendatang, kebanyakan dari mereka bersekolah di pasantren dan sekolah-sekolah islami lainnya. Sedikit sulit untuk menemukan sekolah yang mayoritasnya suku madura. dari temuan dilapangan didaptlah hasil bahwa suku madura telah mengalami beberapa perubahan salah satunya dibidang perekonomian. Hal tersebut berpengaruh terhadap kelanjutan karir siswa setelah SMA yang lebih memilih untuk melanjutkan ke Perguruan Tinggi pada bidang keagamaan dikarenakan memiliki dukungan dari orang tua terutama dari segi materil yang bertolak belakang dari pendapat peneliti sebelumnya yang mengatakan bahwa kebanyakan dari suku madura lebih tertarik untuk berternak dan berkebun.

4. SMA St. Ignasius Singkawang Barat

Hampir $\pm 80 \%$ atau sekitar 716 rata-rata siswa disekolah tersebut memiliki latar belakang suku Tionghoa. Mayoritas siswa berlatar belakang suku Tionghoa menjadi sasaran subjek penelitian yang dilakukan untuk mengetahui arah minat karir siswa setelah lulus SMA. Untuk memperoleh jawaban yang diinginkan, peneliti melakukan wawancara dengan 10 Siswa yang berlatar belakang suku Tionghoa. Pertanyaan yang diajukan kepada responden atau siswa yaitu pertanyaan semi terstruktur yang terkait dengan arah minat karir siswa. Berdasarkan hasil wawancara yang dilakukan, seluruh siswa yang di wawancara memiliki jawaban yang sama mengenai kelanjutan setelah SMA, mereka mengatakan akan melanjutkan ke Perguruan Tinggi namun memiliki bidang masing-masing. Subjek menjelaskan bahwa melanjutkan ke Perguruan Tinggi karena keinginan yang sangat besar didunia fahion dan ingin menjalankan atau meneruskan cita-cita yang dimiliki subjek.

Kota Singkawang merupakan salah satu pecinaan di Indonesia karena mayoritas penduduknya adalah orang Hakka dengan persentase sekitar $42 \%$. Terdapat beberapa sekolah menengah atas yang mayoritas siswanya ber Etnis Tionghoa, salah satunya adalah SMA St. Ignasius Singkawang yang memiliki siswa hampir 95\% ber Etnis Tionghoa.

Hasil dari penelitian yang dilakukan dengan cara mewawancarai subjek yang berlatar belakang etnis tionghoa menyatakan bahwa melanjutkan pendidikan lebih penting untuk mendapatkan 
pekerjaan yang lebih baik seperti dalam bidang kedokteran dan akuntansi. Sebagian dari mereka yang memilih untuk melanjutkan ke Perguruan Tinggi ingin menghapuskan persepsi orang banyak terhadap etnis Tionghoa yang kebanyakan menganggap bahwa pendidikan itu tidap penting. Hal ini berbeda dengan praduga yang dikemukakan peneliti sebelumnya yang mengatakan bahwa pendidikan bukanlah hal yang penting yang perlu dimiliki oleh etnis Tionghoa karena kebanyakan dari mereka lebih memilih untuk langsung bekerja.

\section{KESIMPULAN DAN SARAN}

Berdasarkan hasil penelitian bahwa arah karir minat siswa etnis Tionghoa adalah melanjutkan ke Perguruan Tinggi. Kemudian arah karir minat siswa yang berlatar belakang suku dayak adalah melanjutkna ke Perguruan Tinggi. Untuk Suku Melayu berdasarkan hasil penelitian bahwa arah karir minat siswa yang berlatar belakng suku melayu adalah melanjutkan ke dunia kerja. Dan arah karir minat siswa yang berlatar belakang suku madura adalah melanjutkan ke Perguruan Tinggi. Dengan demikian dapat ditarik kesimpulan bahwa dari keempat suku yaitu suku tiongoa, dayak, melayu, dan madura memiliki kesamaan dalam arah minat karir sepeerti pada ketiga suku yaitu tionghoa, dayak dan madura yang memilih untuk melanjutkan ke Perguruan Tinggi dengan masing-masing bidang yang berbeda sementara pada suku melayu memilih untuk melanjutkan ke dunia kerja.

Beragamnya pilihan karir siswa yang ada, guru Bimbingan dan Konseling dapat merancang dan menjalankan program layanan bimbingan dan konseling yang terkait dengan kelanjutan karir siswa setelah lulus SMA. Dan siswa dapat lebih memantapkan dalam menentukan arah karir sesuai dengan minat yang dimiliki.

\section{DAFTAR PUSTAKA}

Amin, Z. N., Wibowo, M. E., \& Nusantoro, E. (2014). Perbandingan orientasi karir siswa keturunan Jawa dengan siswa keturunan Tionghoa. Indonesian Journal of Guidance and Counseling: Theory and Application, 3(3).

Ardilla, M. S. (2018). Profil Kinerja Guru Bk Pasca Sertifikasi Di Smpn Se-Kota Sungai Penuh Jalilah, J., \& Yasir, M. (2017). Pengaruh Persepsi Terhadap Minat Etnis Tionghoa Kota Banda Aceh Terhadap Perbankan Syariah. ARICIS PROCEEDINGS, (1).

Munadir. (1996). Program Bimbingan Karir di Sekolah. Jakarta:Depdiknas.

Sjamsudin, Helius, (2008). Identitas-identitas Etnik dan Nasional dalam Perspektif Pendidikan Multikultural. Makalah dalam bentuk E-Book.

Supriyono. (2008). Studi Kasus Bimbingan Konseling. Semarang: CV. Niew Setapak. 